\title{
COMPARATIVE STUDY OF IMPLICATION FOR IMPLEMENTING COPYRIGHT LAW AND BOOK LAW IN THE LIBRARY COLLECTION SERVICE
}

\author{
Mohamad Pandu Ristiyono; Ratna Nurhayati \\ Faculty of Social, Law, and Political Science, Universitas Terbuka \\ Email: pandu@ecampus.ut.ac.id; anna@ecampus.ut.a.c.id
}

\begin{abstract}
This article examines the implication of Copyright Law and Book Law implementation of the service in the library. The research method used is normative juridical legal. The correlation between the Book Law, Law on Handover of Print and Recorded Works and the Library Law, both are lex specialist derogate generalist of the Copyright Law or not, according to the author is the adoption or depiction of the fair use and fair dealing doctrine as which is the social function of copyright. The Copyright Law provides protection for Author and Copyright Holder with exclusive rights to be exploited. Related to the Law on Handover of Print and Record Works which gives the obligation of the Author or Copyright Holder to deposit their work for the purpose of preservation and other social purposes to the library which is regulated in the Library Law.
\end{abstract}

Keywords: Copyright Law; Book Law; Fair use; Fair dealing doctrine.

\section{INTRODUCTION}

Library institution as information managers will provide and put attempt and efforts to increase the amount of content and collections in order to fulfill maximum services which compatible with the expectations of both library users in the academic world and even society in general. In the digital era, which is currently in the 4.0 era, information transaction activities take place more dynamically and in a large number of frequencies or can be said to be mass for each day. The internet has encouraged various information institutions, including libraries to leverage the capabilities of the internet or the digital era to provide maximum services and able to reach without limits on time and place.

As in general books, periodicals or publication of information in various formats, both print and softcopy of library main collections are very closely related to Intellectual Property Rights, especially in Copyright. In terms of theoretical and practical dimensions, two inherent rights of the Author or Copyright Holder are attached. These rights include economic rights and moral rights. In the definition stipulated in Law Number 28 of 2014 on Copyrights (hereinafter referred to as the

\footnotetext{
$234 \quad$ Yustisia Volume 8 Number 2 (May-August 2019) $\quad$ Comparative Study Of Implication ...
}

C2019; This is an Open Acces Research distributed under the term of the Creative Commons Attribution Licencee (https://Creativecommons.org/licences/by/4.0), which permits unrestricted use, distribution, and reproduction in any medium, provided the original works is properly cited. 
Copyright Law) defines that economic rights are the exclusive right of the Author or the Copyright Holder in order to gain economic benefits from the Works. Whereas moral rights are rights to maintain the integrity of the works from any other party's intervention which possible to damage the creativity of the Author or Copyright Holder.

In addition to the provisions of intellectual property rights which need to be considered in the provision of literacy services. In Indonesia there are provisions of Law Number 3 of 2017 on The Book Collection System (hereinafter referred to as the Law on Book Collection System). The legal provisions specifically Article 57 states that electronic book development may carried out through:

1) Publishing Manuscript Books in electronic; and

2) Converting printed books into electronic books.

In further provisions of the Law on Book Collection System, Article 59 paragraph 1 till paragraph 3 states that:

1) The main textbooks can be converted into electronic books in order to make it easier for people to get and access the main textbooks;

2) Electronic books as referred to in paragraph (1) can be downloaded for free and duplicated

3) Provisions regarding the conversion into electronic books as referred to in paragraph (1) shall be regulated by a Ministerial Regulation

The existence of the provisions of the Law on Book Collection System especially in Article 57 and Article 59 certainly raises an issue of whether the Law is positioned as a lex specialist derogate generalist to the provisions of the Copyright Law or vice versa? Meanwhile, on the other hand especially in the concept of Intellectual Property Rights or in this case Copyright provides a protection for the results of human thought (creativity) as outlined in a work protected by the state with exclusive rights granted to individuals or in this case the author (Kukuh Tejomurti, 2017: 63). Therefore, it can withdraw a conclusion that Copyright is a private right, where the protection system supports the establishment of a documentation or publication system for the form of a work, so that the possibility of producing prior arts can be avoided or prevented.

Whereas in the Copyright Law especially in the provisions of Article 47 states Every non-commercial library or archival institution may reproduce 1 (one) copy of the Works or part of the Works without permission from the Author or the Copyright Holder by:

1) Reprographic reproduction of a writing that has been published, summarized, or abrdged to meet the demand of a person that:

a. the library or the archival institution ensures that the copy will only be used for educational or research purposes; 
b. the Reproduction is made separately and if it is repeated, that Reproduction must constitute unrelated events; and

c. no License is offered by the Collective Management Organization for the library or the archival institution in regard to the reproduced section

2) the reproduction of copies is for preservation, replacement of required copies, or replacement of copies in the event that the copy is lost, damaged, or destroyed from the permanent collection at the library or other archival institutions provided that:

a. it is impossible for the library or the archival institution to obtain a copy in reasonable conditions; or

b. the making of the copy is conducted separately or if done repeatedly, the making of copies must be unrelated events.

3) the reproduction of copies is intended for the purpose of interlibrary, interarchival institutions, and between library and archival institution Communication or information exchange.

The basic concept of Intellectual Property Rights protection or in this case Copyright as has been said by Robert Sherwood is Risk Theory to discuss the essence of Intellectual Property Rights as legal protection because it contains a risk (Sudrajat, 2010: 60). The risk here refers to the interests of individuals in personal, collective, and legal entity for the existence of a potential violation of exclusive rights or related which obtained economic rights illegally or against the law by other individuals. Therefore, the purpose of Intellectual Property Rights protection is the economic or private interests of the individual owner of exclusive rights.

In related with that, in practice due to disharmony and unclear provisions, a sizeable perception difference arises. In the group of librarians and libraries with one another, so the research team wanted to conduct research in several public tertiary libraries, especially in several state tertiary universities. Based on observations that there are 2 (two) different groups of views, the first group that is, considers duplicating in any form and reason is a violation of copyright, the second group, believes that duplicating books or library collections is not a violation of copyright, because there are normative provisions.

Thus, in providing services to the various types of collections it has, libraries in general and in particular at libraries in tertiary institutions need a careful step and process in order the service fulfils the demanded information of the users and are in accordnace with the applicable provision. Because if a library can avoid the practice of copyright infringement by implementing regulations for its users, libraries, especially tertiary libraries, can be used as role models in the enforcement and dissemination of copyright. Based on the foregoing description, the formulation of the problem in this article is what are the Implications for the Implementation of the Copyright Law and the Law on Book Collection System? 


\section{RESEARCH METHODS}

In this article, the authors will use the normative legal research method which is a method of legal writing based on legal theories, literature and in force legislation in society (Soerjono Soekanto, 2008: 42). The authors will conduct research based on legal theories as well as copyright theory, literature and legislation and other relevant references both for review to find implications due to the implementation of the Copyright Law and the Book Law in Universities. More specifically, the author will deeply examine the legislation related to providing Library Collection Service in universities.

The authors will also use a conceptual approach that moves from the opinions or doctrines which develop in the concept and theory of fair use (Peter Mahmud Marzuki, 2014: 177). Theories and concepts of copyright, the fair use doctrine, will be examined in more depth to find the core of fair use assessment. Furthermore, the basic concept of fair use is analyzed as a basis for determining implications due to the implementation of the Copyright Law and the Book Law in the provision of library collections in universities. Therefore, discovering of how should the practice of providing appropriate book collection services in order not to violate copyright is conducted, but may still demand the development of education in Indonesia.

\section{RESEARCH RESULT AND DISCUSSION}

\section{A. Comparative Study Of Implication For Implementing Copyright Law And Book Law In The Library Collection Service}

In this section, the authors will perform analisys regarding the rules associated with existing problems with the described foregoing theory. The authors will also put an effort to try to find an appropriate correlation between each of these regulations. The related regulations are as follows.

\section{Law Number 28 of 2014 on The Copyright}

The Copyright Law provides protection of a work with exclusive right of the Author or the Copyright Holder in order to gain economic benefits from the works (Law Number 28 of 2014 on Copyright, Article 8). As a result, the author can monopolize the rights, especially economic rights. One of the rights inherent in the protection of copyright is the right to obtain economic benefits from the work of reproducing both works and copies in all of its forms (Law Number 28 of 2014 on Copyright, Article 9). Books are one type of work that is protected by copyright, in the multiplication or duplication of books, it is imperative to get permission from the Author or Copyright Holder (Law Number 28 of 2014 on Copyright, Article 40). 
The concept of IPR protection, especially in the case of copyright illustrates as if IPR is a monopoly system that is capitalist, individualist, and only concerned with the interests of right-holders from the protection of IPR. It raises an impression that there are only few social roles and functions of IPR (Kanti Rahayu, 2014: 36).

The social function of IPR plays a role in maintaining a balance between the interests of individuals (Author or Copyright Holder) with the public interest. The urgency of copyright protection is the balance between rights and obligations. If further observed, especially in the historical process of its protection, it is not only intended to protect the rights and obligations of the author, but also the rights and obligations of the community as users of the creation. The community has a role and is a party that needs the use of creation (Suyud Margono, et all, 2002: 18).

The main focus is changed to no longer the author's rights, but the factor of public interest also shall be paid an attention. The social function can be in the form of giving access to the community, allowing users of certain works and certain ways without permission, or allowing people to use or utilize the work properly, this is what is commonly called the fair use or fair dealing doctrine (Henry Soelistyo, 2010: 86). In Indonesia, the Copyright Law concerning the fair use or fair dealing doctrine use the term copyright restriction (exclusion) which is a form of concern for the existence of the public interest.

In accordance with the provisions contained in the Copyright Law, fair use or fair dealing is contained in Chapter VI concerning Restrictions on Copyright, that is in Article 43 to Article 49. To summarize the research, in the articles related to copyright restrictions, the author will only mention relevant provision to this research, especially related to copyright on books. Article 43 of the Copyright Law states that Acts that are not considered as Copyright infringements include:

1) Publication, Distribution, Communication, and/or Reproduction of State emblems and national anthem in accordance with their original nature;

2) Any Publication, Distribution, Communication, and/or Reproduction executed by or on behalf of the government, unless stated to be protected by laws and regulations, a statement to such Works, or when Publication, Distribution, Communication, and/or Reproduction to such Works are made;

3) Taking of actual news, either in whole or in part from a news agency, Broadcasting Organization, and newspaper or a. Announcement, Distribution, Communication and / or Duplication of national symbols 
and national anthem according to their original nature; other similar sources provided that the source is fully cited; or

4) The production and distribution of the Copyrighted content through information technology and communication media that are not commercial and/or lucrative for the Author or related parties, or the Author expresses no objection to the manufacture and dissemination in question.

5) Reproduction, Publication, and/or Distribution of Portraits of the President, Vice President, former Presidents, former Vice Presidents, National Heroes, heads of State institutions, heads of ministries/ nonministerial government agencies, and/or the heads of regions by taking into account the dignity and appropriateness in accordance with the provisions of laws and regulations.

Article 44 paragraph (1) of the Copyright Law states Use, retrieval, Reproduction, and/or change of Works and/or Related Rights products in whole or substantial part are not regarded as a Copyright infringement if the source is mentioned or cited in full for the purpose of:

1) education, research, scientific writing, report writing, writing of critique or review of a problem without prejudicing the reasonable interests of the Author or the Copyright Holder;

2) security and governance, legislative, and judiciary;

3) talks that are only intended for the purpose of education and science; or

4) performances or shows that are free of charge provided that they would not prejudice the reasonable interests of the Author.

Further, regarding to the portection of copyrighted book, Article 46 paragraph (1) states that Reproduction for personal use of Works that has been published may only be made for 1 (one) copy and may be carried out without permission from the Author or the Copyright Holder. In Article 46 paragraph (2), it mentioned that the Reproduction for personal purposes as referred to in section (1) does not include an entire or a substantial part of a book or musical notation. Subsequently, in paragraph (2) letter e states that Reproduction for personal purposes of which exercise contravenes the reasonable interests of the Author or the Copyright Holder.

The Copyright Law in this article is the core or basis for the regulation regarding copyright restrictions of several other relevant regulations. This is due to the fact that the Copyright Law contains the doctrine of fair use or fair dealing as the basis for the validity of the use of the work by the community without requiring permission or fees on terms and purposes 
that are considered reasonable. Further explanation will be contained in the related regulations or the next section.

\section{Law Number 13 of 2018 on The Handover of Print and Recorded Works}

Handover of print and record works in several countries has certain terms that is the obligation of creation deposit (legal deposit). Historically, deposits of creation have had arrangements for hundred of years. The first practice was carried out in 1537 when King Francois in France issued the Ordonnance de Montpellier. The regulation prohibits the sale of any book without first giving a copy to the royal palace library (Jules Lariviere, 2000: 6).

In its principle, the system of deposit creation is intended for the development and preservation of national book collections as publication material. The handover of printed and recorded works is actually an important matter for several reasons, such as preserving national cultural heritage, creating national collections, including research or documentation purposes, and many other purposes (Ben White, "Guaranteeing Access to Knowledge: The Role of Libraries", http://www.wipo.int/wipo_magazine/en/2012/04/ article_0004.html, Accessed on 25 June 2019).

Article 3 of Law Number 13 of 2018 on The Handover of Print and Recorded Works states that the implementation of handover of print and Recorded Works aims to:

1) realize national collections and preserve them as a result of the nation's culture in order to support development through education, research, and development of science and technology; and

2) save the Print and Record Works from the threat of danger caused by nature and/or human actions.

Observing at the history, before there was Law Number 13 of 2018 on The Handover of Print and Recorded Works, the regulation on creation deposits was regulated in Law Number 4 of 1990 on The Handover of Print and Recorded Works. In this previous law, Soekarman explained that the basis for the emersion of the law was the desire to collect and preserve national collections; guarantee the completeness of national collections; a means of learning, research and information in various scientific disciplines; become a means of compiling national, regional, and various scientific subjects; and providing statistical compilers for the production of printed works and national records (Soekarman Kartosedono, 2011: 245).

The essence of the the emersion of the law in Indonesia is that the Indonesian people must preserve the work of the nation's people therefore the law requires the publisher and record businessman to submit his work 
to be managed to the party appointed in the law, which in this case is the National Library and the Provincial Library. The management is carried out by the National Library and the Provincial Library covering acceptance, procurement, enumeration, processing, storage, utilization, preservation and supervision. The management is also carried out by taking into account the protection of intellectual property rights of each work (Law on Handover of Print and Recorded Works, Article 15).

Another reason for the regulation of depositing this work emerged, was due to the concerns or fears from educational institutions, research, and libraries when they were taking or quoting other people's creations without permission which possible to raise problems. Whereas if considered from the previous explanation, social functions in IPR is necessary, however it shall also have certainty. Therefore, the emersion of the law was due to the lack of social function (Nadya Athira, 2018: 27).

The copyright restrictions in the Copyright Law also indirectly regulated the creation deposit, or it can be said to be the basis of the restriction of the creation. Based on Article 43 and Article 44 of the Copyright Law, accompanied with Article 47 which regulates Every non-commercial library or archival institution may reproduce 1 (one) copy of the Works or part of the Works without permission from the Author or the Copyright Holder. Despite the article, the deposit for the creation is not regulated further in the Copyright Law, but in the Law on Handover of Printed and Recorded Works. Therefore, the implication of the Copyright Law itself is only as a basis for the restriction of the creation or the doctrine of fair use and fair dealing, not to directly regulate the implementation of the deposit of the work (Nadya Athira, 2018: 39).

Regulations requiring deposits made by and to related parties, technical, sanctions and their implementation are regulated more completelyin the Law on Handover of Copyrighted Works and Recorded Works. The parties that have the obligation to make a deposit of creation such as the Issuer, Producers of Recorded Works, state institutions, ministries, non-ministerial government agencies, universities, regional governments, and regional people's representative councils, the community. In essence, all parties who have printed or recorded works as creations both inside and outside Indonesia, if it is related to Indonesia's national interests, it is necessary to make a deposit of the work (Law Number 13 of 2018 on The Handover of Print and Recorded Works). Article 6 paragraph (1) and paragraph (2) of the Law on Handover of Copyrighted Works and Recorded Works state that: 
1) Printed and / or Recorded Works in Indonesia produced through research by Indonesian citizens published abroad must be submitted to the National Library.

2) Printed and / or Recorded Works about Indonesia and made in Indonesia produced by foreign nationals published and / or published abroad must be submitted to the National library.

From this explanation it does not mean that there will be an opinion that the Copyright Law was made because of the Law on the Handover of Print and Recorded Works, the two laws have different concepts. The Copyright Law regulates copyright protection does not require depositing inventions for preservation and is used as public education material. The obligation is contained in the Law on Handover of Print and Recorded Works, therefore creation deposit to be kept are preserved and utilized in accordance with the purpose of the Law on Handover of Print and Recorded Works, whereas in relation to copyright, only the provisions of Copyright Law which are fully applicable (Nadya Athira, 2018: 106-108).

These two regulations are actually complementing each other. This is because the Law on the Handover of Print and Record Works regulates the management of works in the form of printed works and record works such as books, songs, etc. are not regulated in the Copyright Law because it does not regulate for this purpose. Thus these two regulations do not contradict or do not violate each other due to different objectives and concepts. Therefore, in pratice the two regulations are completing each other.

\section{Law Number 3 of 2017 on The Bookkeeping Systems}

Based on the mandate contained in the 1945 Constitution of the Republic of Indonesia, the Indonesian state has a goal to build the nation's civilization by developing the use of science through books as an effort to educate the nation's life and improve public welfare. In an effort to realize the objectives, the state has the obligation to be able to provide adequate educational facilities and infrastructure including ensuring open access to knowledge. This requires that the state must be able to ensure the availability of books in the community (Elga Andina, 2011: 80). Further provisions on bookkeeping are contained in Law Number 3 of 2017 on The Bookkeeping Systems, which in Article 4 states that the operation of the bookkeeping system is aimed at:

1) grow and strengthen the love of the motherland and build national identity and character through the formation of the Bookkeeping System; 
2) regulate and realize the Book System and increase the quality and amount of book resources to produce Book Quality, cheap, and evenly distributed;

3) fostering the literacy culture of all Indonesian citizens; and

4) enhance the role of bookkeeping actors to promote Indonesian national culture through books in the midst of world civilization.

Book is one of the works that has the greatest value in life, because the book is the source of all knowledge in civilization. Before this era, the book was described as writing or printing on a piece of paper or other material that is put together (bound) so that it can be opened on the parts which want to read, and has a cover to protect the inside (Aryani Nauli Hasibuan, 2011: 92).

Books in any kind, whether magazines, newspapers, books, etc. Which have made as a repository of various kinds of science and information cannot deny the effects of the information digitalization. Indonesia is now starting to enter the digital era, where many things that can usually be seen in physical form can now be found in digital or electronic form. The effect of this digitalization on the books is the emergence of a new version of the book, that is in the form of digital, commonly known as e-books or electronic books or electronic books (Muchtar Anshary Hamid Labetubun, 2018: 139).

In an effort to follow these developments, the Book Law also follows the current era to accommodate the regulation of the book system. The definition of books in Article 1 number 2 of the Book Law is expanded as follows, books are written works and/or picture published works in the form of printed copies or in the form of electronic publications which are published periodically. This definition accommodates both printed or physical books and electronic books.

This is confirmed in Article 5 of the Book Law which states that the form of books consists of printed books and electronic books. The printed book in question is a written work in the form of text, pictures, or a combination of both published in printed and electronic form. While electronic books are written works in the form of text, images, audio, video or a combination of the whole which are published in electronic form.

Based on the objectives of the Indonesian state and also in the Book Law, it requires to educate the nation by providing quality, inexpensive and equitable books (Opening of the 1945 Constitution and Law Number 3 of 2017 on The the Book System). Increasing the interest of reading in Indonesia has become one of the preferred programs by the government (Suharmono Kasiyun, 2015). To realize this, quality, inexpensive, and equitable distributed 
books seem to be an important slogan to be realized. The development of printed books into electronic books can be said as an effort to facilitate the realization of quality, inexpensive and equitable books.

Even so, each form of the book has advantages and disadvantages. Digitizing books has advantages in terms of accessibility, functionality, and cost-effectiveness (Dave Gunn, 2016). The high price is one of the shortcomings in the print book trade. This is due to the long distribution process, up to the distributor stage increasing to 60 percent of the initial price of the publisher which resulted to the difficulties to reach the books. The next drawback arises from the uneven distribution of publishing locations, as a result of the book distribution activities being the most dominant in certain islands. Nearly 80 percent of the publication is in Java, which caused an increase in the price of books sent to areas outside of Java. The distribution of bookstores experienced obstacles in remote areas, with limited access the price of books become even more expensive (Elga Andina, 2011 : 89).

The development of electronic books is one of the solutions to realize quality, inexpensive and equitable books. In Article 57 of the Book Law states that the development of electronic books can be done through; a) publishing manuscripts of the book in the form of electronic book; and b) converting printed books into electronic books. Furthermore, Article 59 of the Book Law states that the conversion of the main (printed) textbooks into electronic books is carried out to facilitate the public to obtain and access the main textbooks. The electronic books referred to above can be downloaded for free and duplicated.

However, if considering the other regulation, books become one of the manifestations of written works in the protection of IPR. As stated in Article 40 paragraph (1) letter a of the Copyright Law that Protected Works which include scientific, artistic, and literary Works, comprise: books, pamphlets, typholographical arrangement of published written work, and all other written works; in this case, the published book needs to get protection as a form of appreciation for the creator. Book copyright protection follows all the arrangements in the Copyright Law, for example the moral rights and economic rights inherent in the Author and Copyright Holder of the books.

Article 9 of the Copyright Law states that an Author or Copyright Holder has the economic right to do:

1) publication of the Works;

2) Reproduction of the Works in all its forms;

3) translation of the Works;

4) adaptation, arrangement, or transformation of the Works; 
5) Distribution of the Works or their copies;

6) the show Creation;

7) performance of the Works;

8) Publication of the Works;

9) Communication of the Works; and

10) rental of the Works.

Further, Article 9 paragraph (2) and paragraph (3) of the Copyright Law states that Every Person who exercises the economic rights as referred to in section (1) is obligated to obtain permission from the Author or the Copyright Holder and every person is prohibited from exercising Reproduction and/or Commercial Use without any permission from the Author or the Copyright Holder. If it is related to Article 57 of the Book Law, the implication of the activity is the development of electronic books which are included in the multiplication and/or use of works in the form of books, if intended for commercial purposes, it is required to ask permission from the Author or the Copyright Holder.

It is different if the development of electronic books is intended for noncommercial use. As examined in Article 43 till 49 of the Copyright Law, Copyright Restrictions is included the fair use and fair dealing doctrines. The use, duplication and so on if it is not intended for commercial activities can be done without permission from the Author and Copyright Holder, especially in educational activities, research, scientific papers and so on. Therefore, the development of the main textbooks (printed) which are converted into electronic books if it is not intended for commercial purposes, as well as complying the conditions stated in the Copyright Law, then it is not required permission from the Author and the Copyright Holder.

\section{Law Number 43 of 2007 on The Libraries}

The library is a place for collection of library materials for reading, learning, reference additions, services and other uses. Various kinds of collections in the library can be in the form of scientific works such as books, journals, final projects, magazines and other non-scientific works such as comics, fiction novels, and others (Amalia Tri Asmara Rotari, 2017). In the explanation contained in Law Number 43 of 2007 on The the Library (Library Law) explains, to realize Article 31 paragraph (2), Article 32, and Article 28 letter F of the 1945 Constitution of the Republic of Indonesia, the government needs to organize the library as the most democratic means for learning throughout life in order to fulfill the community's right to obtain information through library services to educate the nation's life. The purpose 
of establishing a library (Law Number 43 of 2007 on The Library, Article 4) is to improve the intelligence of the nation's life through the development and utilization of libraries as sources of information in the form of written books, printed books, and recorded books.

The Library law states that the library is an institution that manages the collection of written works, printed works, and/or recorded works in a professional manner with a standardized system to meet the educational, research, preservation, information, and recreational needs of the visitors (Law Number 43 of 2007 on The Library, Article 1 paragraph 1). Whereas what is meant by library collections are all information in the form of written works, printed works, and/or recorded works in various media contained educational value, which are collected, processed, and served (Law Number 43 of 2007 on The Library, Article 1 paragraph 2).

Examined based on the meanings and objectives in the Library law, it is as if describing the close relationship between the library and the implementation of the creation deposit. The existence of authorized institutions for creation deposits, such as libraries, is also as important as the creation deposits itself. As a gateway to knowledge and culture, libraries play a fundamental role in society. The resources and services they offer create opportunities for learning, support literacy and education, and help shape new ideas and perspectives that are important for creative and innovative societies. They also help ensure authentic records of knowledge created and accumulated by past generations (Ben White, "Guaranteeing Access to Knowledge: The Role of Libraries", http:/www.wipo.int/wipo_magazine/ en/2012/04/article_0004.html, accessed on 25 June 2019).

The function of the library in the Library law is a vehicle for education, research, preservation, information, and recreation to increase intelligence and empowerment of the nation (Law Number 43 of 2007 on The Library, Article 3). Libraries which carry out their functions as information centers that collect writing are also a collection of protected copyrighted works. The pattern of collecting works or creations (such as libraries) is possibly clash with copyright protection. On the one hand, the works that have been created by Author and Copyright Holder become an incentive to form the core of collections in the library, and help the authors as a means of publication. But on the other hand can restrict the community, researchers and librarians in carrying out development missions, research, even teaching and learning (Association of Research Libraries, Code of Best Practices In Fair Use for Academic and Research Libraries: 1). 
In the provisions of the Library law there are Articles which possible to directly intersect with the protection of copyright, for example, from the work patterns of libraries which directly compile collections of works for use by visitors. And frther in Article 7 paragraph (1) letter d, it states that the government is obliged to guarantee the availability of diversity of library collections through translation, transliteration (transliteration), transfer of voice to writing (transcription), and transfer of media (transmedia). Transmedia is the transfer of the form of library materials from printed forms to other media, such as microfilm, CD, and digital.

The entire library collection is selected, processed, stored, served, and developed in accordance with the interests of users by taking into account the development of information and communication technology (Law Number 43 of 2007 on The Library, Article 12 paragraph 1). The forms of transfer and development of the library collections in the form of the work will be in direct contact with the copyright protection of the author or the copyright holder, therefore it shall be carefully conducted to avoid violation.

The library has a key role in the generation to generation of knowledge distribution in the world. On one hand, the function of the library is clearly not socially commercial in nature which makes the utilization of the collected works should not require permission in accordance with the doctrine of fair use and fair dealing (Adler, Prudence, et all, 2010: 2). However, according to the regulation of copyright restrictions in the Copyright Law, there are conditions that must be obeyed in order to perform appropriate use of copyright in the category of copyright restrictions (fair use or fair dealing).

Article 47 of the Copyright Law stipulates that every non-commercial library or archival institution may reproduce 1 (one) copy of the Works or part of the Works without permission from the Author or the Copyright Holder by:

1) Reprographic reproduction of a writing that has been Published, summarized, or abridged to meet the demand of a person provided that:

a) the library or the archival institution ensures that the copy will only be used for educational or research purposes;

b) the Reproduction is made separately and if it is repeated, that Reproduction must constitute unrelated events; and

c) no License is offered by the Collective Management Organization for the library or the archival institution in regard to the reproduced section.

2) the reproduction of copies is for preservation, replacement of required copies, or replacement of copies in the event that the copy is lost, 
damaged, or destroyed from the permanent collection at the library or other archival institutions provided that:

a) it is impossible for the library or the archival institution to obtain a copy in reasonable conditions; or

b) the making of the copy is conducted separately or if done repeatedly, the making of copies must be unrelated events.

3 ) the reproduction of copies is intended for the purpose of interlibrary, interarchival institutions, and between library and archival institution Communication or information exchange.

Further, Article 48 stipulates that Reproduction, Broadcasting or Communication of Works for information purposes that specifies the source of and the name of the Author in full are not considered as Copyright infringements provided that the Works are in the form of:

a) articles in various fields that have been Published both in printed media and electronic media, unless its copy is provided by the Author, or is related to the Broadcasting or Communication of the Works;

b) reports of actual events or short excerpts of the Works that are viewed or listened to in certain situations; and

c) scientific papers, speeches, talks, or other similar Works conveyed to the public.

The provisions of Article 49 paragraph (1) stipulate that Temporary Acts of Reproduction of Works are not considered as Copyright infringement if the Reproduction meets the following conditions:

1) it is done during the digital transmission or the production of the digital Works in a storage media;

2) it is done by any Person authorized by the Author to transmit the Works; and

3) it uses any tools equipped with automatic deletion mechanism to prevent such Works to be displayed again.

Under these provisions, it requires that libraries can only make copies or without permission only once as much as 1 time on a protected work. This can only be used in reprographic copy writing without a license offered by the Collective Management Institute. Unauthorized copying can also be carried out for the purpose of maintaining, replacing required copies, or replacing copies in the event that a copy is lost, damaged or destroyed from a permanent collection in the library. 
Preservation is a core function of the library, existing works can serve the community between generations, teachers, students, and researchers (Adler, Prudence, et all, 2010: 13). Basically the library does have features in the collection of works protected by copyright. In the writer's interpretation, the library institution is an institution that has no commercial purpose, therefore in carrying out its functions, the library becomes a good picture in the doctrine of fair use or fair dealing in the social function of copyright protection. However, from the foregoing conditions, copyright restrictions as for the still have more restrictions with the conditions specified. In its application, libraries shall be careful with the copyrights inherent in each creation.

It is due to the demand that the protection function of copyright can still be upheld and the social function of copyright can continue to be enjoyed by the public. Likewise with the missions and objectives of the library can continue to prosper the community. The mission is to collect, organize, preserve, and provide cultural and scientific heritage in the world for present and future generations. The library operates for the public in supporting education and training, access to science, information and culture. Ultimately the library can become an independent and neutral space committed to provide services based on equality and access for everyone (EIFL, Draft Law On Copyright, Including Model Exception \& Limitations for Libraries and Their Users, WIPO, 2016: 43).

Restrictions on copyright can be said to be a manifestation of the copyright social function which also related to the doctrine of fair use or fair dealing (EIFL, Draft Law On Copyright, Including Model Exception \& Limitations for Libraries and Their Users, WIPO, 2016: 43). In some countries, copyright restrictions are made to enable the multiplication of a work which are not qualified as infringement of copyright by conducting it fairly with conditions stipulated in the legislation and court jurisprudence (T. Randolph Beard, et all, 2016: 6). Whereas in considering aspects of losses in copyright infringement, it can be assessed from the liberal-individualistic theory, which based on natural law theory and risk theory (Ari Wibowo, 2015: 73).

Based on foregoing discussion, it is very necessary to pay attention to the importance of balance in protecting copyright and the rights inherent in society. The aspect which shall have considered is the fulfillment of fundamental rights, especially in education as contained in Article 31 of the 1945 Constitution of the Republic of Indonesia. Therefore, the doctrine of fair use/fair dealing copyright on books is very important adjusted to the principles of social functions which makes a crystallization of the communalism values, spiritualism and inclusivism as basic values of Indonesia are translated into the values of Pancasila as the 
nation's philosophy and which animates the 1945 Constitution as the constitution of the Unitary State of the Republic of Indonesia (Anis Mashdurohatun, et all, 2017 : vii).

The doctrine of fair use / fair dealing copyright on library collection books in state and private universities needs to be adjusted to the philosophy of the nation and the state, namely Pancasila. Indonesia as a country based on law, including the category of modern law adherents. Conception of a modern constitutional state can be referred to in the formulation of the State's objectives, namely: protecting the entire Indonesian nation and all spilled Indonesian blood, promoting public welfare, educating the nation's life and realizing social justice (I Gusti Ayu Ketut Rachmi Handayani, 2014: 51-52). In the sentence educating the life of the nation and realizing social justice is the basis of accommodation or adopting the doctor of fair use / fair dealing copyright on library collection books in state and private universities, so that the use of library books can be enjoyed by all components and guaranteed by the state through its legal instruments that are adapted to the ideology of the Indonesian people, namely Pancasila. So based on this there is a relationship between law and ideology that is the reciprocal relationship. Law is not only ideology supported by institutionalized social forces, but also institutionalized social forces that are articulated in and reinforced by ideology, in other words, ideology determines legal products and legal products will strengthen the prevailing ideology (Petrus cCKL Bello, 2013: 34).

Efforts to unite the basic concept of copyright show more liberalindivisualistic side, with communal, spiritual and inclusivism values, which make the doctrine of fair use or fair dealing carry out social functions as listed in Chapter IV Copyright Restrictions on the Copyright Law. It can be said that the doctrine of fair use and fair dealing regardless of what direction the choice of copyright protection in the Copyright Law is contained in copyright restrictions. Apart from any possibilities regaridng the Book Law, the Law on Handover of Print and Record Works, and the Library Law are a lex specialist derogate generalist of the Copyright Law or not, according to the authors, the interrelation of various articles in the regulation which even intersect with each other established the adoption or depiction of the fair use and fair dealing doctrines as the social functions of copyright.

The authors will simply describe the relevance of these regulations from this study. As the foregoing discussion, the Copyright Law provides protection for Author and Copyright Holder with exclusive rights that can be exploited. In Article 40 the Copyright law, states that books are one of the protected works. As regulated in a separately in the Book Law, books are written works and/or picture works published in the form of printed copies or in the form of electronic 
publications which are published periodically. This definiton accommodates that the definition of books regulated in the Book Law is not only books that are printed or physical, but also electronic books, therefore various forms and types of books obtain copyright protection for the Author and Copyright Holder.

Article 28 letter J of the 1945 Constitution of the Republic of Indonesia mandates that the absence of rights which can be fully monopolized and obliged to be subject to certain limitations, for likewise in copyright protection, there needs to be limitations in the rights that have been granted such as social functions which may be utilized by the community. The application of social functions in copyright protection in the book, is reflected in the doctrine of fair use or fair dealing that can be seen in the laws related to this research. In general, many countries in the world apply the fair use and fair dealing doctrine to enable the multiplication of creations, but are not included or qualified as copyright infringement (sanusi Bintang, 1998: 49).

In the Copyright Law, the doctrine of fair use and fair dealing can be seen in Chapter VI on The Limitation of copyrights, Article 43 to Article 49, especially those relating to books are Article 43, Article 44 paragraph (1), Article 46 paragraph (1) and paragraph (2). The Law on Handover of Print and Record Works, gives an obligation to the Author and Copyright Holder holder to make deposits of his creation to the institution to which the government is aiming. This creation deposit aims to preserve national cultural heritage, create national collections, and research or documentation purposes. The existence of library as an authorized institution to make a creation deposit is important as well. The Library law and the Law on Handover of Print and Recorded Works seem to have a close relationship. These conservation efforts have a social function for the development of intergenerational generations, in order to avoid ruled out of any rights. However, the working patterns of collecting a collection of creations in one institution will be in direct contact with the protection of copyright, therefore legal certainty between copyright protection and the needs of the public is needed, which solved by the doctrine of fair use and fair dealing to balance these interests. However, the parties involved, especially those who make use of the creation, need to remain careful by following the conditions so as not to harm the creator and the copyright holder.

The doctrine of fair use and fair dealing in its application raises a lot of debate and difficulties for the community to use. There are many concerns about copyright infringement that occur in using copyright restrictions (Ben Depoorter \& Fransesco Parisi). This is due to fair use or fair dealing does not merely determine "right or wrong" or clearly can be determined, but requires further analysis of each set of circumstances. In this case, the provisions contained in 
the law regarding fair use or fair dealing (especially fair use in the United States) are deliberately made more open and flexible which makes it possible to apply according to the facts and circumstances that occur in each case (Lesley Ellen Harris, 2015).

The authors will give a bit description of the case as a projection of how to apply the doctrine of fair use or fair dealing in copyright protection. After reading in the previous section, the form of the handover of print and record works in a library in relation to copyright protection has several restrictions. During this time, many deposit creations were carried out through file uploads via the internet. This means that the copyrighted works of books (whether journals, theses, theses, reports, or other related matters) are deposited into the library in digital form.

If the librarian or library wants to convert the creation by printing the digital book, does it require permission to the Author and Copyright Holder? This is in accordance with the third part of the Book Law on The the Development of Electronic Books, especially Article 57 and Article 59. Although in that articles state the opposite, when printed book is converted into an electronic book, the authors argue that if it is in the same goal which is to facilitate the public to obtain and access books or aim to preserve the existing collection of books, then this is the same.

In this circumstance, the conformity with the doctrine of fair use and fair dealing that allows reproducing works without permission and does not violate copyrights justified if the purpose is for educational purposes, public discussion, or others that are not included in commercial activities (Ariel Katz, 2012: 3). The conversion of the creation in a digital library collection into a printed form, with the aim of adding to the library's collection is clearly not purposed for commercialization. It can also analyze these cases through factors that can be considered in the use of fair use or fair dealing.

The initial factor is the purpose and character of the use of the work, which is the main factor that decides whether an act includes a fair use qualification or not. It may simply be conducted by testing whether there is a profit motive derived from the use of the work (William F Pantry and Shira Perlmutter, 1993). As the purpose of the case description is to add to the library collection by printing books (creations) into the form of printed works. In certain circumstances it can even be repeated, the existing collection of books will be lent to the public, and whether the conditions of the loan have a fee collection or not? This depends on the policies of each library. However, usually borrowing books from a library is free of charge, moreover the library of a college for students or the community is usually free of charge. As supported by the arguments in the theory section above, usually the court is more supportive of the use of creatures that are transformative 
(Copyright Advisory Office, What is Fair Use?, https://copyright.columbia.edu/ basics/fair-use.html accessed on 25 June 2019). Conversion can be said to have the same meaning as the use of creatures that are transformative. Therefore, the objective factors and character of the use, in this case, are included in the qualifications of the fair use or fair dealing doctrine.

The second factor is the nature of published works. This factor itself in the United States rarely appears in related cases, which makes this factor has the least influence from the fair use analysis factor. The form of the first publication is taken into consideration in factors for fair use reason (D. Naver, 1997: 105). In the description of existing cases, the first publication of the creation deposited to the library is in the form of digital, while in the process of conversion it will be converted into a printed form. The existing conversion is able to change the nature of creation with an objective that will also change. In the second factor, the description of this case fits into the qualifications of the fair use or fair dealing doctrine. But if examined further in the description of the fair use doctrine, this factor has a close relationship with the fourth factor, that is the economic effect of the use of the work, where if a work has properties that are very similar to the market for which the copyrighted work is intended, then the fair use reason may be dismissed (Arthur R. Miller and Michael H. Davis, 1984: 355). Regarding this, the authors will explain further on the fourth factor later.

The third factor is the amount and substance of the portion of the work used. In this factor, the principle usually used is "the more the taking, the more the infringement", or it can be said that the less that is taken, the greater the action is in the fair use doctrine (March Lindsey, 2003). Indeed, when viewed from this factor, the description of existing cases can be said to be rejected to qualify the fair use doctrine. The process of converting a work (book) from digital into a printed form, directly takes the entire portion of the amount and substance of the work. But this is different when applied in matters involving library activities. A little extra explanation because the doctrine of fair use in these factors is oriented to the United States, then in Section 108 of the Copyright Act 1976 states it is not an infringement of copyright for a library or archives, or any of its employees acting within the scope of their employment, to reproduce no more than one copy. Likewise in Indonesia, regarding copyright restrictions in library affairs is regulated in a separate article, which the author will explain later. In this third factor, although the case description does not include a fair use qualification, consider the objective and character factors that are not for commercial purposes, the strengthening of these factors is also supported by special regulations in limiting copyright in libraries. 
The fourth factor is the effect of using creation on market potential. This factor will assess the fact that a case will be classified if the impact of the incentives (economic value) on the creator is minimal or small (USG Copyright Policy, The Fair Use Exception, https://www.usg.edu/copyright/the fair_use exception accessed on 25 June 2019)

. This factor has links with other factors, for example with the nature factor of creation. If the nature of the work is also used for similar fields with similar potential profit, then the reason for fair use can be rejected (Arthur R. Miller and Michael H. Davis, 1984: 355). In the description of existing cases, an electronic book with a predetermined market by the Author and Copyright Holder, for example, students or lecturers, will indeed affect the market potential because it does not rule out the possibility of an option to borrow books from the library instead of buying the book. However, when viewed from the impact of the loss, this is felt to be very minimal, for example copyright restrictions require that only 1 (one) copy which may be made, then access to books that can be borrowed at the library is only very little in a limited time. So that people who need the book if they really want it easier and not limited to reading the book, still have to buy books from the Author and Copyright Holder. Therefore, according to the authors, in the description of existing cases, it still falls into the fair use classification because the impact of incentives (economically) is only minimal.

If observing from the statutory regulations in Indonesia, the relevant provision of the Copyright Law can be seen in Article 47 which stipulates that Every non-commercial library or archival institution may reproduce 1 (one) copy of the Works or part of the Works without permission from the Author or the Copyright Holder by:

a. Reprographic reproduction of writing that has been Published, summarized or abridged to meet the demand of a person provided that:

1. the library or the archival institution ensures that the copy will only be used for educational or research purposes;

2. the Reproduction is made separately and if it is repeated, that Reproduction must constitute unrelated events; and

3. no License is offered by the Collective Management Organization for the library or the archival institution in regard to the reproduced section.

b. The reproduction of copies is for preservation, replacement of required copies, or replacement of copies in the event that the copy is lost, damaged, or destroyed from the permanent collection at the library or other archival institutions provided that:

1. it is impossible for the library or the archival institution to obtain a copy in reasonable conditions, or 
2. the making of the copy is conducted separately or if done repeatedly, the making of copies must be unrelated events.

The law allows libraries to copy or make copies, but with conditions that must be met. As a mandate in the Law on Handover of Printed and Recorded Works to realize national collections and preserve the nation's culture, which has the same interrelated interests with the library as the authorized institution in depositing this creation. Whereas in the Article 7 paragraph (1) letter d of Library Law states that the government is obliged to guarantee the availability of library collections diversity through translation, transfer of letters (transliteration), transfer of voice to writing (transcription), and transfer of media (transmedia). Transmedia is the transfer of the library materials form from printed forms to other media, such as microfilm, CD, and digital. Then it becomes according to the transmedia form from digital to print form to be carried out, which proposed for preservation.

In addition to the Book Law also mandates that Article 57 of the Book Law states that the development of electronic books can be done through; a) publishing book manuscripts in the form of electronic books, and b) converting printed books into electronic books. Furthermore, Article 59 of the Book Law states that the conversion of the main (printed) textbooks into electronic books is carried out to facilitate the public to obtain and access the main textbooks. Therefore, in the description of existing cases, to be in accordance with the reasons for the preservation of digital books, it is necessary to make copies in printed form.

However, it is still necessary to pay attention to the conditions contained in the Copyright Law, especially the copyright restriction section, such as the conversion from digital books to electronic books or vice versa as copies can only be made 1 (one) for maintenance purposes, if the library is not possible to obtain copies in reasonable conditions, or the making of the copy is conducted separately or repeatedly, the making of the copy must be an unrelated event. Duplication can also be done by the library to fulfill a person's request with the condition that the library is able to assure that it is only used for educational and research purposes, further, any repeated copy must be an unrelated event, and no license is offered from the Collective Management Institute. If this is complied by the library, then it may be included in the fair use classification.

In the description of the case, it is indeed too simple, but it can at least illustrate that the application of the doctrine of fair use or fair dealing or copyright restrictions is not easy, not clearly determined "right or wrong" but needs further analysis depending on each case. In Indonesia, there are only a few cases which in defense reasons for the application of the doctrine of fair use or fair dealing or copyright restrictions, is different from in the United States which was even made a decision index database by the United States Copyright Office that can 
be used to see jurisprudence in previous cases as research material as well as for the defense reasons of a case (Lesley Ellen Harris, 2015). This is very helpful in a court system with the common law model (Gerald Postema, 2003).

In addition, prior research conducted by Retno Sari Widowati, Sentot P. Sigito, and M. Zairul Alam who examined by comparing the application of the principle of fair use related to book propagation policies in Indonesian and Australian tertiary libraries. The study was conducted in Indonesia at libraries in Universitas Brawijaya and Universitas Airlangga which both have regulations from the Chancellor, which does not provide explicit policies regarding the multiplication and propagation of creation. It only describes and explains the rules for the review of books with sanctions, not specifically giving strict rules related to the creation. Whereas in Australia, research was conducted on Wollongong University library policies that have very strict copyright protection, such as library copyright policies, basic copyright, and library code of ethics rules. There are terms and conditions which only allow any copy if it does meet the requirements stated in the Australian Copyright Law to copy a shift in time, space, purpose, format. However, all staff and students are strictly prohibited from using infrastructure for copying or for entertainment purposes (Retno Sari Widowati, et all, 2015: 5-8).

It is then being a solution to facilitate the process of analyzing the doctrine of fair use and fair dealing, a checklist can be made as implemented by several agencies in the United States. The checklist is made simple to be applied even by people who have not learned about the law. The checklist is as contained in appendix 1. It is expected that the existence of "tools" made like this can make it easier for the public to use copyright restrictions for the purposes set out in the law and the losses suffered by the Author and Copyright Holder in order to avoid violations of copyright.

Implications of the Copyright Act and the Act as the author discussed earlier, based on data from the observation team of writers to several libraries in universities, especially on the island of Java, while still accommodating requests from such turnover that is disguising the name of the institution (institution). In subject X, starting from 2 (two) years before, 144 lost books/collections and the lost collections were replaced by students with original books or proportional copies, which is replacing 97 original books and replacing copies. as many as 47 pieces of collection. On the subject of library Y starting from 2 (two) years earlier, 177 lost books/collections were lost and the collections were replaced by students with original books or proportional copies, ie replacing 91 original books and replacing them in the form of copies. as many as 86 pieces of collection. Whereas for subject $\mathrm{Z}$ starting from 2 (two) years before 107 books/collections 
were lost and the lost collections were replaced by students with original books or proportional copies, ie replacing 87 original books and replacing copies. as many as 20 pieces of collection. Based on this it can be said that the libraries in several state universities on the island of Java there is a policy of allowing can not be separated from the normative provisions that exist both in the provisions of the Copyright Law and Other Laws as discussed by the author and also several libraries in these universities carry out Presidential Instruction No. 8 of 2016 dated August 26, 2016 to carry out austerity measures in the framework of implementing the Revised State Budget $(A P B N-P)$ of the Fiscal Year from 2016 to the present.

\section{CONCLUSION}

The need to adjust the concept of copyright protection which is capitalist, individualist, and only concerned with the Author and Copyright Holder with Indonesia's basic values that hold the values of communalism, spiritualism, and inclusivism, with social functions reflected in the doctrine of fair use and fair dealing, makes Indonesia regulate copyright restrictions. The correlation between the Book Law, Law on Handover of Print and Recorded Works and the Library Law, both are lex specialist derogate generalist of the Copyright Law or not, according to the author is the adoption or depiction of the fair use and fair dealing doctrine as which is the social function of copyright. The Copyright Law provides protection for Author and Copyright Holder with exclusive rights that can be exploited. In Article 40 of the Copyright Law, books are one of the protected works. Regarding books, it has been regulated in a separately in the Book Law, which regulates that books are not only printed but also electronic or digital to protect various forms and types of books.

Article 28 letter J of the 1945 Constitution of the Republic of Indonesia mandates that no rights can be fully monopolized and must be subject to certain restrictions. Likewise in copyright protection, there are copyright restrictions which are social functions that reflect the doctrine of fair use and fair dealing. In essence, this doctrine permits the multiplication of creations but is not included or qualified as infringement of copyright. Related to the Law on Handover of Print and Record Works which gives the obligation of the Author and Copyright Holder to deposit their work for the purpose of preservation and other social purposes to the library regulated in the Library Law. With the working pattern of collecting a collection of creations, such as books in one institution will be in direct contact with copyright protection, it is necessary to have legal certainty to balance copyright protection with the community demands. Therefore, the role of the doctrine of fair use and fair dealing in Indonesia is known as copyright restrictions to accommodate any effort to balance the interests. 


\section{BIBLIOGRAPHY:}

\section{Books:}

Adler, Prudence, Brandon Butler, Patricia Aufderheide, and Peter A Jaszi. (2010). Fair Use Challenges in Academic and Research Libraries. Washington, DC: Association of Research Libraries.

Ariel Katz. (2018). Debungking the Fair Use vs. Fair Dealing Myth: Have We Had Fair Use All Along?

Association of Research Libraries. (2012). Code of Best Practices In Fair Use for Academic and Research Libraries. Washington

Athira, Nadya. (2018). Legal Review of Deposits of Creation (Tinjauan Hukum tentang Deposit Ciptaan). Skripsi, Depok: Fakultas Hukum Univer sit a s Indonesia.

Ben Depoorter \& Fransesco Parisi. (2000). Fair Use and Copyright Protection: A Price Theory Explanation. Belgium: Center for Advanced Studies in Law and Economics. Ghent University.

Bintang, Sanusi. (1998). Copyright Law (Hukum Hak Cipta), Bandung: Citra Aditya Bakti

C. Anwar. (1999). Copyright Infringement and New Copyright Laws in Indonesia (Pelanggaran Hak Cipta, dan Perundang-undangan Baru Hak Cipta di Indonesia). Jakarta: Novindo Pustaka Mandiri.

D. Naver. (1997). Intellectual Property Law: Copyright, Patent, Trademark, Ontario: Irwin Law.

Dave Gunn. (2016). Accessible eBook Guidelines for Self-Publishing Authors, Accessible Books Consortium (the International Authors Forum)

EIFL. (2016). Draft Law On Copyright, Including Model Exception \& Limitations for Libraries and Their Users. WIPO

Eric M. Dobrusin, Ronald A. Krasnon. (2008), Intellectual Property Culture: Strategies to Foster Successful Patent and Trade Secreat Practices In Everyday Business. Oxford University Press

Hariwijaya and Triton. (2007). Thesis Writing Techniques (Teknik Penulisan Skripsi dan Tesis). Yogyakarta: Oryza

Hasibuan, Aryani Nauli. (2011). Perlindungan Hak Cipta Atas Karya Derivatif Dalam Prakteknya: Studi Kasus Buku Ensikopedia Al Quran: Al-Maushuah Al Quraniyah Al-Muyassarah. Jakarta: Master Thesis, Faculty of Law, Universitas Indonesia. 
Irianto, Sulistyowati and Shidarta. (2011). Legal Research Methods "Constellation and Reflection (Metode Penelitian Hukum "Konstelasi dan Refleksi"). Jakarta: Yayasan Obor Indonesia

Lariviere, Jules. (2000). Guidelines for Legal Deposit Legislation (A Revised, enlarged and updated edition of the 1981 publication by Dr. Jean Lunn). Paris: United Nations Educational, Scientific and Cultural Organization

Lindsey, March. (2003). Chapter Five: The Mystic Doctrine of Fair Use in Copyright Law on Campus, 17, Washington: Washington State University Press.

Margono Suyud and Amir Angkasa. (2002). Commercialization of Intellectual Asset Aspects of Business Law (Komersialisasi Aset Intelektual Aspek Hukum Bisnis). Jakarta: Grasindo.

Marzuki, Peter Mahmud. (2014). Legal Research (Penelitian Hukum), Jakarta: Prenadamedia Group

Mashdurohatun, Anis (2008). Mengembangkan Fungsi Sosial Hak Cipta Indonesia (Suatu Studi Pada Karya Cipta Buku). Surakarta: UNS Press

Mashdurohatun, Anis. (2018). Hak Cipta atas Buku Model Fair Use/Fair Dealing, Hak Cipta atas Buku dalam Pengembangan IPTEKS Pada Pendidikan Tinggi. Depok: Raja Grafindo Persada,

Michael, ed. (2013). The Copyright Pentalogy: How the Supreme Court of Canada Shook the Foundations of Canadian Copyright Law, Ottawa. ON: University Press

Miller, Arthur R., et all. (1984). Intellectual Property. Minnesota: West Publishing Company.

Nugraheni, Catur Nugraheni. (2014). Book Propagation for Educational Interest in a Copyright Perspective: Analysis of Providers of Photocopy Services (Perbanyakan Buku Untuk Kepentingan Pendidikan dalam Perspektif Hak Cipta: Analisis Terhadap Penyedia Jasa Fotokopi). Skripsi, Fakultas Hukum Universitas Indonesia

Petrus cCKL Bello. (2013). Legal Ideology Reflections on the Ideology Behind Philosophy of Law (Ideologi Hukum Refleksi Filsafat Atas Ideologi Di Balik Hukum). Bogor: Insan Merdeka

Ratnajati, Diyah. (2008). Comparison of Fair Use Doctrines on the Internet between the United States and Indonesia (Perbandingan Doktrin Fair Use Pada Internet Antara Amerika Serikat dan Indonesia). Semarang: Master Thesis, Faculty of Law, Universitas Diponegoro.

Soekanto, Soerjono. (2008). Introduction to Legal Research (Pengantar Penelitian Hukum). Jakarta: Penerbit Universitas Indonesia.

Soelistyo, Henry. (2008). Plagiarism Infringement of Copyright and Ethics (Plagiarisme Pelanggaran Hak Cipta dan Etika). Yogyakarta: Kanisius.

\footnotetext{
\begin{tabular}{ll|l}
\hline Yustisia Volume 8 Number 2 (May-August 2019) $\quad$ Comparative Study Of Implication ... & $\mathbf{2 5 9}$
\end{tabular}
} 
Soelistyo, Henry. (2015). Copyright Without Moral Rights (Hak Cipta Tanpa Hak Moral). Jakarta: Raja Grafindo Persada.

Sudrajat. (2010). Intellectual property rights; Understand the Basic Principles, Coverage and Applicable Laws (Hak Kekayaan Intelektual; Memahami Prinsip Dasar, Cakupan, dan Undang-undang yang berlaku). Bandung: Oase Media.

The World Book Encyclopedia. (1984). Volume 2, World Book, Inc.

William F Pantry and Shira Perlmutter. (2010). Fair Use Misconstrued: Profit, Presumption, and Parody,11 Cardozo Arts \& Ent. L.J. 667,676, 1993

Willian Van Caenegem. (2001). Intellectual Property, New South Wales: Butterworths.

\section{Journals:}

Andina, Elga. (2011). Buku Digital dan Pengaturannya, Pusat Pengkajian Pengolahan Data dan Informasi Sekretariat Jendral DPR RI, Aspirasi Volume 2 Number 1.

Anshary, Muchtar and Hamid Labetubun. (2018). Aspek Hukum Hak Cipta Terhadap Buku Elektronik (E-Book) sebagai Karya Kekayaan Intelektual, SASI Volume 24 Number 2, 2018

Copyright Advisory Office, What is Fair Use?, https://copyright.columbia.edu/basics/ fair-use.html accessed on 25 June 2019

D’Agostino, Gluseppina. (2008). Healing Fair Dealing? A Comparative Copyright Analysis of Canada's fair Dealing to U.K Fair Dealing and U.S. Fair Use, McGill LawJournal, Volume 53,

Dan, Thu Thi Phan, Will Fair Use Function on the Internet?, The Columbia Law Review, 1998

Handayani, I Gusti Ayu Ketut Rachmi. (2014). Kedaulatan Sumber Daya Alam Di Indonesia Sebagai Aktualisasi Nilai-Nilai Pancasila. Jurnal Hukum Yustisia. Volume 3 Number 1

Harris, Lesley Ellen. (2015). Applying Fair Use In Your Library, Dow Jones \& Co, Information Outlook. Volume 19 Number 03.

Kasiyun, Suharmono. (2015). Upaya Meningkatkan Minat Baca sebagai Sarana untuk Mencerdaskan Bangsa, Jurnal Pena Indonesia (JPI), Volume 1 Number 1.

Kukuh Tejomurti. (2017). The Personal Electronic Data Security on The Implementation of Solo Smart City According to The Perspective of Privacy Protection Law, Journal of Law, Policy, and Globalization, Volume 66 (2017). See: https//iiste.org./journals/index.php/JLPG/issue/view/3228

Mashdurohatun, Anis, and M. Ali Mansyur. (2017). Model Fair Use/Fair Dealing Hak Cipta Atas Buku dalam Pengembangan IPTEK pada Pendidikan Tinggi. Jurnal Hukum Ius Quia Iustum Number 1 Volume 24

2601 Yustisia Volume 8 Number 2 (May-August 2019) Comparative Study Of Implication ... 
Nola, Luthvi Febryka. (2011). Pelaksanaan UU No. 4 Tahun 1990 tentang SerahSimpan Karya Cetak dan Karya Rekam: Analisis Yuridis Kewenangan dan Koordinasi Antara Perpustakaan Daerah dengan Pihak Terkait”, Negara Hukum: Volume 2 Number 2, November 2011

Postema, Gerald. (2003). Classical Common Law Jurisprudence, Oxford University Commonwealth Law Journal.

Rahayu, Kanti. (2017). Kajian Hukum tentang Penerapan Fungsi Sosial Hak Cipta (Copyleft) di Indonesia. e-journal, Universitas Pancasakti, Tegal.

Rotari, Amalia Tri Asmara. (2017). Sikap Pustakawan Terhadap Pelanggaran Hak Cipta atas Buku. Jurnal, Universitas Airlangga.

T. Randolph Beard, George S. Ford dan Michael Stern, Fair Use in the Digital Age, Phoenix Center Policy Paper Number 51, 2016

USG Copyright Policy, The Fair Use Exception, https://www.usg.edu/copyright/ the_fair_use_exception accessed on 25 June 2019

White, Ben, "Guaranteeing Access to Knowledge: The Role of Libraries”, http:// www.wipo.int/wipo_magazine/en/2012/04/article_0004.html, accessed on 25 June 2019.

Wibowo, Ari. (2015). "Justifikasi Hukum Pidana terhadap Kebijakan Kriminalisasi Pelanggaran Hak Cipta, serta Perumusan Kualifikasi Yuridis dan Jenis Deliknya". Jurnal Hukum Ius Quia Iustum Number 1 Volume 22

Widowati, Retno Sari, et all. (2015). Penerapan Prinsip Fair Use Dalam Hak Cipta Terkait Dengan Kebijakan Perbanyakan Buku Di Perpustakaan Perguruan Tinggi (Studi Perbandingan Hukum Berdasarkan Undang-Undang Hak Cipta Di Indonesia Nomor 28 Tahun 2014 Dan Australia), Jurnal, Fakultas Hukum Universitas Brawijaya.

\section{Legal Documents:}

1945 Constitution of the Republic of Indonesia

Law Number 43 of 2007 on The Library (State Gazette of The Republic of Indonesia Number 129 of 2007);

Law Number 28 of 2014 on Copyright (State Gazette of The Republic of Indonesia Number 5599 of 2014);

Law Number 3 of 2014 on Bookeping (State Gazette of The Republic of Indonesia Number 158 of 2014);

Law Number 13 of 2018 on The Handover of Print and Recorded Works (State Gazette of The Republic of Indonesia Number 265 of 2018);

U.S. Copyright Act 1976

Yustisia Volume 8 Number 2 (May-August 2019)

\begin{tabular}{l|l} 
Comparative Study Of Implication ... & $\mathbf{2 6 1}$
\end{tabular} 